\title{
Catholics and Non-Christians in the Archbishopric of Goa
}

\author{
Provincial Councils, Conversion, and Local Dynamics in the Production of \\ Norms (16th-18th Centuries)
}

\section{Patricia Souza de Faria}

\section{Introduction}

In 1567, the First Provincial Council of Goa was held in the city that became the seat of the homonymous Archbishopric and capital of the Portuguese conquests located in Asia. Within the scope of the Portuguese overseas empire, the Provincial Councils of Goa stand out for the relative regularity with which they were held, totaling five councils celebrated between 1567 and 16o6, and for their role in the production of ecclesiastical legislation to be applied in territories and societies as diverse as those under the jurisdiction of the Archbishopric of Goa.

This chapter analyzes how the relationship between Catholics and non-Christians was intended to be governed by the Church and the Portuguese Crown in the Archbishopric of Goa. By analyzing the decrees of the Provincial Councils of Goa as well as some specific regulations utilized in the Estado da India, the actions aimed at promoting the conversion of local populations and eradicating non-Christian beliefs can be examined. Simultaneously, it is necessary to consider the multiple concrete circumstances in which Catholics and non-Christians coexisted and interacted in the territories of the Estado da Índia.

The first section discusses the nature of the Portuguese presence in the Indian Ocean and its establishments, demonstrating that the ecclesiastical organization of the Estado da Índia was built amid a diversity of establishments and communities under the influence-directly or indirectly-of the Portuguese Crown. The second section summarizes the historical contexts and main products of the five Provincial Councils of Goa. Additionally, the essence of the decrees contained in the Second Action of the minutes from these councils are analyzed, with attention to the regulations aimed at dealing with non-Christian social groups and the idealized means for promoting conversions to Catholicism in the Archbishopric of Goa. The determinations 
contained in the minutes of the councils concerned with favoring the conversion of those the Portuguese Crown called "Gentile vassals" who lived in the Portuguese Asian empire are also considered.

The last section analyzes the complex and dynamic process of the production of norms in the Archbishopric of Goa by emphasizing how the decrees of the Provincial Councils of Goa, and other laws of the Estado da Índia, dealt with the issue of guardianship of orphans of Gentile parents, one of the means adopted to stimulate the conversion of native populations. The conversion policy of orphans is examined considering aspects from the context in which the first norms on the matter were formulated, in the 16th century, to the debates that took place in the context of the transformations of the Estado da Índia, between the decades of 1670 and 1720 .

Accordingly, this chapter presents an overview of the establishment of the Archbishopric of Goa and the Provincial Councils before focusing on the analysis of the minutes from these councils-and other laws of the Estado da India-looking at how they dealt with a very controversial topic within the scope of the religious policy adopted in the Archbishopric of Goa: the withdrawal of orphaned children of Gentile parents from the kin group to be given to Christian tutors. It was believed that this practice would have a significant potential to multiply conversions, not only because orphaned boys and girls would be instructed in the Christian faith, but also because family members would be encouraged-coerced - to convert to Catholicism so that the children were not taken from them. This chapter also situates the roles of two local agents whose functions were inextricably linked to the converted native populations and the orphans of non-Christian parents: the Pai dos Cristãos (Father of Christians) and the Conservador e Juiz dos Cristãos da Terra (Judge of the Christians of the Land).

Within the broad possibilities related to the conversion policy, this study focuses on the issue of orphaned children of Gentile parents, not only because it allows a glimpse of a very conflicting facet of the relationship between Christians and non-Christians; the controversies surrounding the laws aimed at the conversion of these children and their relatives also allow for the analysis of rulemaking in the Estado da Índia, considering the role of different local agents (judges, the Pai dos Cristãos, viceroys, Gentile families) in the construction of norms. As mentioned, the minutes of the Provincial Councils of Goa, as well as royal letters, orders from viceroys of the Estado da Índia, opinions from theologians, and petitions of the native population that were transmitted to the authorities of the Estado da Índia or to the King of Portugal are consulted and cross-checked as documentary sources. 
Before a closer analysis of conversion policies and the decrees of the Provincial Councils of Goa, it is necessary to consider the nature of the Portuguese presence in the Indian Ocean and its establishments. Essentially, the Estado da Índia was a network (a communication system across various spaces), marked by the heterogeneity of institutions and the imprecision of its territorial and legal limits, that supported agreements, conquests, and Portuguese sovereignty in the East Africa and Asia. ${ }^{1}$ The formal empire was characterized by areas directly controlled by the Portuguese Crown, such as the region of Goa, or forts and cities under the jurisdiction of the viceroy of the Estado da Índia. With regard to the informal empire, there were communities of Portuguese people with autonomous status who adopted Portuguese civil institutions; Portuguese people who acquired land, villages, and jurisdiction over populations in regions outside the formal borders of the empire; and Portuguese mercenaries who acted according to individual interests or those of the African or Asian armies they served. ${ }^{2}$

Pontifical documents gave shape to the rights of patronage in the Portuguese overseas territories so that the King of Portugal, as administrator of the Order of Christ, became the main agent responsible for evangelization in his conquests, for the creation and maintenance of the local churches, ${ }^{3}$ and for exercising the prerogative to propose the creation of dioceses and the appointment of bishops, subject to the Pope's confirmation. ${ }^{4}$ In 1534, the Bishopric of Goa was created, which came to have spiritual jurisdiction over territories from the East African coast to the Far East. According to the author Catarina Madeira-Santos, the introduction of diocesan jurisdiction corresponded to the duplication of Goa's centrality with it becoming both a political and ecclesiastical center of the Estado da Índia. ${ }^{5}$ In 1557, the Bishopric of Goa was elevated to the status of Archbishopric, while the ancient geographical domains under its administration were dismembered to form the suffragan dioceses of Cochin and Malacca. In 1575, the diocese of Macau was created, covering the

\footnotetext{
1 Thomaz, De Ceuta a Timor, 207-210.

2 Newitt, "Formal and Informal Empire in the History of Portuguese Expansion".

3 The Padroado corresponded to privileges associated with certain obligations that the Church granted to the founders of churches, chapels, or benefits, such as, the presentation of candidates for an ecclesiastical office and the administration of tithes. Gonçalves, "Padroado"; Xavier and Olival, "O Padroado da Coroa de Portugal: Fundamentos e Práticas".

4 Sá, "Estruturas Eclesiásticas e Acção Religiosa”, 267.

5 Madeira-Santos, Goa é a Chave de Toda a Índia. Perfil Político da Capital do Estado da Índia (1505-1570), 201.
} 
Christianity of China and Japan, and this was dismembered in 1588 with the creation of the diocese of Funai (Japan). In short, the Archbishopric of Goa had jurisdiction over the Bishoprics of Cochin, Meliapor, Malacca, Macau, and Funai, as well as the Territorial Prelature of Mozambique (created in 1612) and the Bishoprics of Nanjing and Beijing (created in 169o). ${ }^{6}$

The territorial circumscription of the dioceses varied over time. The Archbishop of Goa had ordinary jurisdiction over the Portuguese possessions of Goa, Daman, and Diu, regions where the Portuguese Padroado established parishes; missions founded in Konkan and Karnataka, south and east of Goa; and churches built under the Padroado, north of Goa, and in Vasai and Bombay. The diocese of Cochin administered ecclesiastical affairs in southern India and Ceylon until it was dismembered in 1606, giving rise to the diocese of Saint Thomas of Mylapore. The diocese of Angamale was created in 1600 but transferred to Cranganor five years later, in addition to incorporating almost all the Saint Thomas Christians (Syrian-Malabar rite) who were forced to adopt the Roman Catholic rite. ${ }^{7}$

When analyzing the rules adopted in this multifaceted Portuguese Asian empire, one finds "a chaotic compound of legal regimes, combining the diversity of a very metropolitan law with a wide array of particular legal orders, local usages and judicial styles". ${ }^{8}$ Following the considerations of António Manuel Hespanha, Madeira-Santos states that the legal and jurisdictional pluralism of Portuguese origin became expandable to the empire's spaces, with its potential for adaptation. ${ }^{9}$ This flexibility became advantageous in the management of the empire, which combined a multiplicity of kingdoms, protectorates, neighboring kings (allies or enemies), and populations less integrated in the empire's borders, which could be managed pragmatically based on the human and economic resources available. ${ }^{10}$ It should be added that evangelization in

6 Coutinho, Le Régime Paroissial des Diocèses de Rite Latin de l'Inde des Origines (XVIe Siècle) à nos Jours; Sá, "Estruturas Eclesiásticas e Acção Religiosa".

7 The Diocese of Angamale-Cranganor resulted from the incorporation of communities of native Christians from the Malabar Coast. From the papal brief In supremo militantis ecclesiae (160o), the diocese came to belong to the Portuguese Padroado (from 16oo), but the imposition of the Latin rite encountered difficulties since the majority of the Christians of that community lived outside the Portuguese domains. Bethencourt, "A Igreja", 376 .

8 Hespanha, "Uncommon Laws. Law in the Extreme Peripheries of an Early Modern Empire", 86.

9 Madeira-Santos, "O Império Português Face às Instituições Indígenas (Estado da Índia, Brasil e Angola, Séculos XVII-XVIII)”, 276.

10 Hespanha, "Uncommon Laws. Law in the Extreme Peripheries of an Early Modern Empire", 201. 
the context of missions meant that Christian populations located beyond the borders of Goa and the Estado da Índia, because they were subjected to the canonical jurisdiction of Portuguese bishops, indirectly became subjects of the King of Portugal to some extent. ${ }^{11}$

The decrees of the Provincial Councils of Goa have provisions considering the different statutes of the territories, the different degrees of vassalage, and the different confessional ties. In the first place, a good part of the decrees clearly focuses on the conquests and peoples that were subjected to the politicalmilitary control of the Portuguese Crown. However, it is necessary to consider that within these settlements there were distinct human groups under which specific norms, restrictions, or privileges fell: Catholics of European origin; Saint Thomas Christians or other Christians who did not follow the Latin rite; natives converted to Catholicism; and non-Christians (Jews, Muslims, Gentiles).

Finally, it is worth noting that a local institution was created in the 1530 s to deal with conversion issues. The Pai dos Cristãos was a lay position, however, it came to be occupied by members of religious orders in the main conquests and fortresses administered by the Portuguese Crown in the Estado da Índia. The main duties of the position involved preventing the practice of "idolatry", granting favors and privileges to those who converted, teaching Christian doctrine, guaranteeing the baptism of catechumens, and supporting converts. The Pai dos Cristãos had to visit the villages to learn about the orphans and catechumens-orphans who were children of "infidels" would be collected at the Colégio de São Paulo. ${ }^{12}$

According to Joseph Wicki, the institution of the Pai dos Cristãos existed exclusively in the Portuguese missions in the East. In a way, it can be considered a singular office associated with the Portuguese presence in Asia. However, there are some similarities in relation to other offices established in the spaces of Iberian colonization as local ways of dealing with indigenous populations, such as the case of the Procurador de Índios in Brazil ${ }^{13}$ or the protector de indios in Hispanic America. ${ }^{14}$ The Procurador de Índios in Brazil acted as an assistant and lawyer for the indigenous people, however, he had no jurisdic-

11 Xavier and Olival, "O Padroado da Coroa de Portugal: Fundamentos e Práticas", 146-147.

12 Wicki, O Livro do Pai dos Cristãos, 14-17.

13 Ferreira, "Nas Malhas da Liberdade: O Tribunal da Junta das Missões e o Governo dos Índios na Capitania do Maranhão (1720-1757)", 9o; Mello, "Sobre as Apelações de Liberdade dos Índios na Amazônia Portuguesa no Século XVIII".

Cardim, "Os Povos Indígenas, a Dominação Colonial e as Instâncias da Justiça na América Portuguesa e Espanhola". 
tional function, forwarding cases to the governor and Crown judge. ${ }^{15}$ In India, the Governor Francisco Barreto issued a provision that attributed to the Pai dos Cristãos of Goa the role of judging the quarrels between Christians, as long as they were minor. ${ }^{16}$ In this sense, according to Hespanha, the Pai dos Cristãos acquired the role of "private judge of the Christianized indigenous people".17

Ângela Barreto Xavier considers that, in a second conjuncture in 1581, an attempt was made to reduce the religious action established in the villages of Goa so that the position of Conservador e Juiz dos Cristãos da Terra, responsible for judging cases involving native Christians, was created. ${ }^{18}$ The provision determined that the viceroy should appoint a literate judge to hold this position. ${ }^{19}$ Although it is possible to locate provisions that continued to grant such assignments to the Pai dos Cristãos, in the 168os, permits reiterated the role of viceroys in appointing judges to serve as Conservador e Juiz dos Cristãos da Ter$r a,{ }^{20}$ whose Rules of Procedure are analyzed at the end of this chapter, in the midst of the controversies surrounding the conversion of orphaned children of Gentile parents.

This section situates the context in which the norms related to the conversion policy in the Archbishopric of Goa were formulated. Some scholars affirm that, in the initial decades that followed the conquest of Goa (in 1510), a religious policy prevailed which was characterized by the tolerated coexistence of Catholics and non-Christians. ${ }^{21}$ Around the 1540s, there was a turning point in religious politics ${ }^{22}$ that coincided with the political-religious reform that had developed during the reign of D. João III. ${ }^{23}$ Thus, a second phase, roughly between the decades of 1540 and 1570, was characterized by the broad incen-

\footnotetext{
15 Mello, "Sobre as Apelações de Liberdade dos Índios na Amazônia Portuguesa no Século XVIII".

16 Xavier, A Invenção de Goa: Poder Imperial e Conversões Culturais nos Séculos XVI eXVII, 183.

17 Hespanha, Cultura Jurídica Europeia - Síntese de Um Milênio.

18 Xavier, A Invenção de Goa: Poder Imperial e Conversões Culturais nos Séculos XVI e XVII, 101 and 184.

19 Wicki, O Livro do Pai dos Cristãos, 71-74.

$20 \quad$ Wicki, $O$ Livro do Pai dos Cristãos, 292-294 and 300.

21 Mendonça, Conversions and Citizenry: Goa under Portugal. 1510-1610, 250-255.

22 Tavares, Jesuitas e Inquisidores em Goa.

23 Xavier, A Invenção de Goa: Poder Imperial e Conversões Culturais nos Séculos XVI e XVII.
} 
tive to proselytize, in which context the Jesuits arrived in India (in 1542) and the Court of the Holy Office of Goa was created (in 1560).

During the reign of D. João III, the regency of D. Catarina, and the reign of D. Sebastião, anti-Hindu laws and decrees were produced, leading to the establishment of decrees in favor of Christianity, including laws that prevented non-Christians from occupying offices in the Estado da Índia, in addition to granting other privileges exclusively to converts. Laws passed during the government of D. Pedro Mascarenhas (1554-1555) maintained the focus of stimulating conversions and preventing Hindu or Muslim religious ceremonies, as well as determining that orphans of Hindu parents should be removed from the relationship with their relatives and receive a Christian education. ${ }^{24}$ Thus, except for Francisco Barreto, between $155^{\circ}$ and 156o, the governors were closely aligned with bishops — and later with archbishops—and with Jesuits concerning the religious policy favorable to conversions. ${ }^{25}$

The laws instituted in the 1540 s and 156 os contained some central guidelines that were recorded in the minutes of the First Provincial Council of Goa in 1567 and were taken up again in later Provincial Councils. When the First Council was called, D. Gaspar de Leão was leading the Archbishopric of Goa, but he received the Pontiff's consent in relation to his resignation request, whereby D. Jorge Themudo became his successor in conducting the activities and concluding the minutes of the council. The First Council was celebrated when D. Antão de Noronha (1564-1568) was governor of the Estado da Índia, during which he received several royal letters determining that he would prioritize conversions in India. One of the actions in favor of the conversions adopted in his government was the approval of the law that determined the surrender of orphans of Gentile parents to the Jesuits. ${ }^{26}$ The minutes of the First Council were sent to the governor so that they were examined and gave rise to the letter passed in legal form by him ${ }^{27}$ approving almost all of the decrees, demonstrating the complex overlap between political and ecclesiastical powers in the construction of norms in the Estado da Índia.

After the First Provincial Council of Goa in 1567 , four other councils were held. One of the determinations of the Council of Trent was the periodic

24 Araújo, "O 'Pay Dos Christãos'. Contribuição para o Estudo da Evangelização da Índia", 306; Mendonça, Conversions and Citizenry: Goa under Portugal. 1510-1610, 258-259.

25 Vila-Santa, "O Vice-Reinado de D. Antão de Noronha no Contexto da Crise do Estado da Índia de $1565^{-1575 " . ~}$

26 Vila-Santa, "O Vice-Reinado de D. Antão de Noronha no Contexto da Crise do Estado da Índia de $1565^{-1575 ", ~} 91$.

27 Rego, Documentação para a história das Missões do Padroado Português do Oriente, vol. 10, 334-335 (hereafter: "DHм PPO"). Vila-santa, "O Vice-Reinado de D. Antão de Noronha no contexto da crise do Estado da Índia de $1565^{-1575 ” . ~}$ 
holding of synods and provincial councils. Indeed, Session XXIV of the Council of Trent reestablished the holding of provincial councils in the places where they had been abolished, with triennial regularity. ${ }^{28}$ Prelates were to meet and draft constitutions associated with the sacraments, religious rituals, tasks and responsibilities of the clergy, and administration of patrimony and justice, as well as sins and moral deviations. ${ }^{29}$ In Europe, the Kingdoms of Portugal and Spain were among the first to recognize the Tridentine decrees. Meetings were held in 1566 in Portugal, Lisbon, and Braga and the following year in Évora. From the Iberian kingdoms, the decrees of the Council of Trent were disseminated to the respective colonial spaces. ${ }^{30}$

Thus, the Second Provincial Council was celebrated in Goa in 1575 during the government of Antônio Moniz Barreto $\left(1573^{-1577)} \cdot{ }^{31}\right.$ As a result of the death of D. Jorge Themudo, Pope Gregory XIII ordered that D. Gaspar would resume the role of Archbishop of Goa, conducting the Second Provincial Council. In the midst of political disputes, D. Gaspar was the one who executed the royal order of deposition of the Viceroy D. António de Noronha in 1573, who was succeeded by Barreto. Barreto supported the role of the archbishop in the Second Provincial Council, but it was D. Gaspar's last attempt to try to apply the conversion policy more austerely, through the close connection between political and religious power. ${ }^{32}$ The Third Provincial Council of Goa took place in 1585 under the leadership of Archbishop D. Vicente da Fonseca during the government of Viceroy D. Duarte de Meneses (1584-1588). The Fourth Council was held in 1592, conducted by D. Mateus de Medina and the Fifth was celebrated in 1606, under the leadership of Archbishop D. Aleixo de Meneses. ${ }^{33}$

These three Provincial Councils took place in the context of the Iberian Union (1580-1640), during the third phase of the religious policy adopted in the Archbishopric of Goa, when the reorientation of the Estado da Índia was taking place, with emphasis on the growing concern about the territorial expansion that, according to Sanjay Subrahmanyam, predates the Habsburg government itself. ${ }^{34}$ This search for the territorial expansion of the Estado da Índia encountered obstacles because of the new political order formed in Asia, exemplified by the expansion of the Mughal Empire. Moreover, the Dutch

Sacrosanto, e Ecumênico Concílio de Trento, sess. 24, cap. 2, 267.

29 Boschi, "Estruturas Eclesiásticas e Inquisição".

30 Silva, "Recepção Do Concílio de Trento em Portugal"; Paiva, "A recepção e aplicação do Concílio de Trento em Portugal".

31 Rivara, Archivo Portuguez-Oriental, fasc. 4, 86 (hereafter: "APO").

32 These statements are based on Vila-Santa, "Revisitando o Estado da Índia nos Anos de 1571 a 1577 ".

33 Wicki, "Die Konzilien der Kirchenprovinz Goa: 1567-1895".

34 Subrahmanyam, O Império Asiático Português. 1500-1700.
} 
and English presence in Asia rivaled Portuguese commercial interests in the Indian Ocean. In this context of external and internal challenges, D. Duarte de Meneses complained about the lack of financial resources as a result of the emigration of Hindus from the lands controlled by the Crown partly due to anti-Hindu laws. ${ }^{35}$ Thus, laws that encouraged conversion continued to be enacted in the period, but governors and viceroys needed to consider their impact on the Estado da Índia's finances in the context of such military and economic challenges.

The expectation surrounding the regularity of such meetings is evident in the minutes of the Fifth Provincial Council of Goa, which determined that the Sixth would be celebrated in January $1616 .^{36}$ If one compares the Church's legislative activity in Portuguese Asia and Portuguese America, the difference is striking; there are no known compilations of ecclesiastical legislation in Brazil in the 16th and 17 th centuries. ${ }^{37}$ In this manner, the Church's legislative activity in the Archbishopric of Goa is more similar to that adopted in the Spanish overseas domains, due to the recurrence of comparable meetings, such as the Provincial Councils of Lima (1551-1552, 1567-1568, 1582-1583) and Mexico $(1555,1565,1585)$, the joint gathering celebrated in Manila (in 1582), and the First Episcopal Synod held in the Philippines, in Cebú, in 16oo. ${ }^{38}$

One of the main objectives of the Provincial Councils was to legislate, according to canon law and the reform implemented by the Council of Trent. Broadly speaking, the minutes of the Provincial Councils of Goa can be divided into four parts: The first contains the presentation of the council, its objectives, and the Tridentine Profession of Faith; the second focuses on the conversion of non-Christians and the treatment of converts; the third addresses ecclesiastical matters, the administration of the sacraments, divine worship, and the behavior of the clergy; while the fourth deals with the reform of customs. In this sense, the Provincial Councils dealt with everything considered convenient to the ecclesiastical provincial, such as provision for the vacancies of churches, absolution of irregularities, promotion of preaching of the Gospel, overseeing the moral behavior of laypeople, fostering of episcopal seminars, and protocols for marriages, masses, and other sacraments. ${ }^{39}$

35 Mendonça, Conversions and Citizenry: Goa under Portugal. 1510-1610, 183 and 267.

36 APO, fasc. 4, 278. The Sixth Provincial Council of Goa only took place in 1894.

37 Boschi, "Os escritos de D. Frei Manuel da Cruz e as Constituições Primeiras do Arcebispado da Bahia", 399-40o.

38 Martínez López-Cano, Concilios Provinciales Mexicanos. Época Colonial; Porras Camúñez, Sínodo de Manila de 1582; Grignani, "La Legislación Eclesiástica de Toribio Alfonso de Mogrovejo, Segundo Arzobispo de Lima: La Regla Consueta y Los Sínodos Diocesanos". Moutin, "Producing Pragmatic Literature in the Third Mexican Provincial Council (1585)", $285^{-286 .}$ 
In addition to decrees, the Provincial Councils were responsible for producing other documents "that acquired normative value". ${ }^{40}$ During the First Provincial Council of Goa, the Constitutions of the Archbishop of Goa were also examined and were printed in 1568. D. Gaspar, in the Prologue to the Constitutions, asserted that each vicar had acted as he saw fit, which was why efforts to standardize ecclesiastical activities were necessary. ${ }^{41}$

The search for standardization in the way of providing instruction in the Catholic faith, celebrating divine offices, and administering the sacraments ${ }^{42}$ among other matters, was one of the objectives of the Provincial Councils, materialized in the form of decrees, Constitutions, and even what Thomas Duve has called "pragmatic literature" — as a legal tool for evangelization, with an emphasis on "their juridical origin" as "canonical documents arranged for a practical use". ${ }^{43}$ By way of comparison, the Third Provincial Council of Mexico approved three catechisms, a directory for confessors and penitents, and a ritual for administering the sacraments. The bishops of the Third Mexican Council asked theologians to develop a catechism for Indians, Africans, and Spaniards, not for the lack of catechisms but in order to search for instruction in the matters of the Christian faith in a standardized way. ${ }^{44}$

Similarly, the First Provincial Council of Goa established that bishops would be in charge of compiling a compendium of Christian doctrine. ${ }^{45}$ Almost twenty years later, the Third Provincial Council of Goa ordered a compendium of Christian doctrine to be created in Portuguese, translated into the native languages, in addition to a brief Tridentine catechism adjusted to the peoples of Asia and approved by the Council. ${ }^{46}$ The Third Council also ordered the production of a summary of the Constitutions and decrees approved in the Provincial Councils of Goa to be handed over to the Bishop of Angamale, in addition to the translation of the Missal and Roman Breviaries, a catechism,

40 Moutin, "Producing Pragmatic Literature in the Third Mexican Provincial Council (1585)".

41 Rego, Dhmpro, Constituições do Arcebispado de Goa, 1568, vol. 10, 484; Xavier, "Gaspar de Leão e a Recepção do Concílio de Trento no Estado da Índia", 145 .

42 Rego, DHmppo, vol. 10, Constituições do Arcebispado de Goa (1568).

43 Duve, "Pragmatic Normative Literature and the Production of Normative Knowledge in the Early Modern Iberian Empires in the 16th-17th Centuries", 20-22; Moutin, "Producing Pragmatic Literature in the Third Mexican Provincial Council (1585)," 292. Moutin, "Producing Pragmatic Literature in the Third Mexican Provincial Council (1585)", 288 .

45 Rego, DHмpPo, vol. 10, 366 (1st Council, action 2, dec. 46).

46 APO, fasc. 4, 139 and 188. BNP, cod. 176, fl. 75r. In the list of books composed by the Jesuits in Asia, it appears as: "Cathecismo, ou práticas, da doutrina Christã [...] feitas pera christãos novamente convertidos destas partes da Índia [...] collegidas do Cathecismo Romano, e universal, e de outros, por ordem do $3 .{ }^{\circ}$ Conçilio Provincial de Goa por hum Padre da Companhia de Jesus em Português". 
a sum of cases (for the use of confessors), and a preaching book to guide priests-documents that aimed to fit the Saint Thomas Christians into the rites and doctrines of the Catholic Church. ${ }^{47}$

The Provincial Councils of Goa ordered and approved the documents cited, but one of their main products was the decrees. Of particular interest are those contained in the Second Action, which sought to establish the norms that would regulate the relations between Catholics and non-Christians, as well as define which principle(s) would demarcate the boundary between means considered lawful and unlawful when seeking conversions.

In summary, the decrees contained in the Second Action have four points worth highlighting. The first is the granting of privileges and favors to converts, such as access to positions in the Estado da Índia, inheritance, and land, while non-Christians would be subject to restrictions, loss of status, and even expulsion from territories administered by the Portuguese Crown. ${ }^{48}$

The second aspect is that although the focus of the decrees was on the prohibition of the use of force, provisions that had the purpose of carrying out coercions in search of conversions predominate. In this sense, one of the orders was that bishops oblige all "infidels" who lived in their diocese and who were over 15 years old to attend preaching in church on Sundays. If the infidels did not do so they could be deprived of trade with the Christians. ${ }^{49}$ Regarding these conciliar decrees, the Viceroy D. Antão de Noronha ordered the production of lists of Gentiles residing in Goa, Vasai, Cochin and Malacca. The purpose of these lists was to define in which parishes the Gentiles had to attend preaching. However, wealthy Hindu merchants who brought income to customs and physicians were excluded from the obligation to listen to the preaching and were not included in these lists. ${ }^{50}$

The third aspect refers to orders for the destruction of images and temples dedicated to local cults. ${ }^{51}$ Christians were forbidden to participate in the rites, celebrations, and weddings of the Gentiles. ${ }^{52}$ The First Provincial Council ordered the expulsion of all "infidels" who held offices equivalent to those of priests or masters of the local religious systems from the territories adminis-

\footnotetext{
47 APO, fasc. 4, 149.

48 Mendonça, Conversions and Citizenry: Goa under Portugal. 1510-1610; Xavier, A Invenção de Goa: Poder Imperial e Conversões Culturais nos Séculos XVI e XVII; Faria, "Os Concílios Provinciais de Goa: Reflexões sobre o Impacto da 'Reforma Tridentina' no centro do Império Asiático Português (1567-16o6)".

49 Rego, DHмPPO, vol. 10, 344.

$50 \quad$ Rego, Dнм PPO, vol. 10, 406.

$5^{1}$ Rego, DHм PPo, vol. 10, 346-347 (1st Council, action 2, dec. 9).

52 Rego, D нм Ppo, vol. 10, 346-348 (1st Council, action 2, dec. 9 and 10).
} 
tered by the Portuguese Crown. ${ }^{53}$ Lastly, the fourth aspect was to try to avoid the cohabitation of Christians with non-Christians, with the hope of avoiding the "contamination" of Christian faith and habits.

According to Luís Filipe Thomaz, the anti-Hindu legislation adopted in Goa could never be put into practice in the places located in the territory of allied Gentile kings in which Portugal did not exercise sovereignty. Similarly, the Portuguese ecclesiastical and civil authorities were unable to implement this legislation in Diu, an important commercial center, where it was essential to maintain forms of coexistence with the merchants operating in the region by guaranteeing them freedom of worship. ${ }^{54}$

It is important to highlight that the general principle present in the minutes of the Provincial Councils of Goa was a prohibition on the use of force in search of conversion, so that the Gentiles could only be led to adhere to the Catholic faith voluntarily. This prohibition is found in the minutes of the First Council, ${ }^{55}$ was repeated at subsequent ones, and is present in the Archbishop of Goa's constitutions. ${ }^{56}$

Ecclesiastics and other participants in the discussions held during the Provincial Councils of Goa faced this fundamental issue, essential in the organization of relations between Catholics and non-Christians, widely addressed by theologians and jurists since medieval times. In the 16th century, theologians discussed this in the legal-theological debates that took place in the Iberian Peninsula. Francisco de Vitoria, for example, postulated about circumstances where there were infidels subjected to Christian princes or those who lived in Christian countries. In such circumstances, should infidels be compelled to receive the Christian faith? In short, Vitoria followed the conclusions of Saint Thomas Aquinas on the prohibition of compelling infidels to accept the Christian faith and baptize children (under the age of reason) against the will of unfaithful parents because, according to natural law, children are governed by parents. ${ }^{57}$

Decrees of the Provincial Councils of Goa that defined the legal means to obtain the conversions would address the aforementioned traditional issues ${ }^{58}$ but what stands out in the decrees is how practices adopted by missionaries

\footnotetext{
53 Rego, Dhmppo, vol. 10, 345-348 (1st Council, action 2, dec. 6 and 9).

54 Thomaz, "Amchi Bhas: O paradoxo linguístico de Goa".

55 Rego, DHмPPO, X, 341 (1st Council, action 2, dec. 1).

56 Rego, DHMPPo, $\mathrm{x}, 499$.

57 Hernández, Derechos Humanos en Francisco de Vitoria: Antología, 179-185; Aquino, Suma Teologica, ed. Ferreira, II ${ }^{\mathrm{a}}-\mathrm{II}^{\mathrm{a}}$, q. 10, a. 8 and 12 and III ${ }^{\mathrm{a}}$, q.68, a. 10.

$5^{8}$ Rego, DHмppo, vol. 10, 343 (1st Council, action 2, dec. 3); APO, fasc. 4, 93 (2nd Council, action 2, dec. 5).
} 
locally, as they caused scandals and raised great doubts about the nature of conversions, were then banned. ${ }^{59}$ In this sense, the First Council ordered that none of the highest caste could eat or drink with those of the lowest and that, if they did, they would soon lose their caste "and remain in the rank and honor of the lowest with which they ate". ${ }^{60}$ This decree determined that "no one should feed these Gentiles against their will, if they do not want to become Christians". ${ }^{61}$ Missionary actions that led to the loss of caste were classified as illicit means of conversion. Regarding the removal of orphaned children of Gentile parents, debates tended to focus on whether it was lawful to baptize children (before the age of reason) without parental consent (a traditional question mentioned above), as well as the definition of an orphan, meaning that this type of conversion was not considered violent and illicit in itself.

\section{The Conversion of Orphaned Children of Gentiles: Laws, Customs, and Local Agency}

To analyze in more detail the complex process of production of norms in the Estado da Índia, the following section places an emphasis on how the decrees of the Provincial Councils of Goa and some laws dealt with the issue of guardianship of orphans of Gentile parents. In the first place, children were not considered to be legal entities as they were under the power of the pater familias, in that the power was an attribute of the father and, if he could not exercise it, he would preferably be replaced by another man. Portuguese law defined that the position of orphan judge should be instituted in all locations that had more than 400 residents and that this judge should appoint a guardian to look after the orphans' assets. ${ }^{62}$ In Goa, boys (up to 14 years old) and girls (up to 12 years old) whose father had died would be handed over to tutors to be educated based on Christian principles. Furthermore, this tutelage also had the

59 Tavares, Jesuitas e Inquisidores em Goa. Missionaries were denounced for exploiting the food bans of Indian populations, forcing them to eat certain foods that made them "unclean". If they lost their caste, they would be rejected by their group of origin. To survive, they would need to convert to Catholicism seeking any favors that the local Church granted to converts. This type of measure to stimulate baptism could cause "scandals", that is, the idea that conversion to Catholicism would not result from the neophyte's will.

6o Rego, DHмPPO, X, 342 (1st Council, action 2, dec. 1).

61 Rego, DHмp>o, X, 342 (1st Council, action 2, dec. 1).

62 Gandelman, "Entre a Cura das Almas e o Remédio das Vidas: O Recolhimento de Órfãs da Santa Casa da Misericórdia do Rio de Janeiro (ca. 1739-1830)", 151; Coates, Degreados e Órfãs: Colonização dirigida pela Coroa no Império Português. 1550-1755, 196 and 256. 
consequence of controlling the assets that orphans would inherit. ${ }^{63}$ In effect, in 1556, Barreto, the Governor of the Estado da Índia, determined that children of Gentile parents would be removed from their families when their father died even when their Hindu mother and relatives were still alive. The orphans would then be handed over to a Christian tutor until they reached the age of reason or 14 years old. ${ }^{64}$

In 1559, the reactions of the non-Christian native population pressured Queen Regent D. Catarina to change the 1556 law, instituting a new decree which determined that only the children of Gentiles in the city and on the islands of Goa who remained without a father or mother and without a grandfather or grandmother, or any other ascendants, and who were under 14 years of age were to be taken by the orphan judge to the Colégio de São Paulo, where they would be indoctrinated in the Catholic faith and routed to the learning of a craft. ${ }^{65}$ In 1564, the Viceroy D. Antão de Noronha, on behalf of King D. Sebastião, confirmed this decree. ${ }^{66}$

At the First Provincial Council, the authorities present alluded to the aforementioned laws on orphans but asked the King of Portugal to determine that every son of an infidel, after his father's death, at an age that was considered an orphan (according to royal ordinances) be handed over to a Christian tutor or guardian. ${ }^{67}$ Thus, the First Council decree sought to reverse the laws of 1559 and 1564, which determined the removal of orphans only if, in addition to the father, they had no other living relatives. ${ }^{68}$

Much of the clergy believed that the coercion linked to the removal of orphans from the mother's care favored her subsequent conversion. The authorities gathered at the Fifth Council asked the viceroy to enforce the laws so that the children, as soon as their Gentile father died, be handed over to a Christian tutor, who could consent to the baptism of orphans who had not reached the age of reason, even against the wishes of the mother or grandparents. ${ }^{69}$ In 1646, forty years after the Fifth Council, the Viceroy D. Filipe de Mascarenhas (1644-1651) reiterated decrees of the First and Fifth Provincial Councils, establishing that the consent of the Christian tutor was enough for

\footnotetext{
63 Robinson, Conversion, Continuity and Change, 48.

64 Mendonça, Conversions and Citizenry: Goa under Portugal. 1510-1610, 205-206.

65 APO, fasc. 5, part. I, 385; Wicki, O Livro do Pai dos Cristãos, 98-99.

66 APO, fasc. 5, part. II, 577; Mendonça, Conversions and Citizenry: Goa under Portugal. 15101610, 207.

67 Rego, DHм Ppo, vol. 10, 35 o (1st Council, action 2, dec. 13).

68 Rego, Dhm pro, vol. 10, $35^{\circ}$ (1st Council, action 2, dec. 13); Mendonça, Conversions and Citizenry: Goa under Portugal. 1510-1610, 207.

69 APO, fasc. 4, 208 (5th Council, action 2, dec. 7); Mendonça, 207-208.
} 
the orphan of Gentile parents to be baptized before reaching the age of reason, even if the mother and other ascendants were opposed to the conversion. ${ }^{70}$

After the aforementioned 1646 decree of D. Filipe de Mascarenhas, the norms that regulated the conversion policy of orphans who were children of Gentiles had another significant change in late 1670 . In the meantime, between the promulgation of the decree of D. Filipe and the junta which met in 1677 to examine the question of orphans, the Estado da Índia and the administration of the Archbishopric of Goa experienced many challenges. In addition to the creation of the Congregation of the Propaganda Fide (in 1622) that brought challenges to the Portuguese Padroado, a long period of suspension of relations between the Holy See and the Portuguese Crown began after the Portuguese Restoration (1640). In addition, between $165^{2}$ and 1670, the Archbishopric of Goa became a vacant seat.

After the surrender of Bombay to the British (in 1665) and the revision of the peace agreements with the Dutch (in 1669), the conjuncture of the 167os, during the regency of D. Pedro, marked the beginning of a neutral policy for the Portuguese Crown relative to other European powers in maritime Asia. There was a need for an economic reorientation to compensate for the losses of the Estado da Índia and one of the responses was to explore the growing demand for Brazilian tobacco in Goa, Macau, and other parts of Asia. Tobacco became the most relevant item in the Lisbon-Goa trade from the end of the 17th century until the end of the 18th century, so that Hindu merchants dominated this lucrative trade. At the same time, importation of different goods in Asia was being resumed, led mainly by Indo-Portuguese, Christian Goans, Saraswat Brahmins, and Banianes. ${ }^{71}$

The regency of D. Pedro and the action of the viceroys and governors of the period (D. Luís de Mendonça Furtado, D. Pedro de Almeida, Antônio Paes de Sande) took place among the seeking of both administrative changes and a balance capable of maintaining religious proselytism, but without economic damage to the Estado da Índia, so that the demands of Gentiles who occupied relevant economic positions could not be neglected. In a letter written in 1671, more than 30 Gentile merchants from Baçaim reported to the Viceroy D. Luís de Mendonça Furtado what they considered to be abuses regarding the compulsory withdrawal of orphans. In 1676, after a new petition from the Gentiles sent to D. Pedro, the regent ordered a board to be convened to examine the topic. ${ }^{72}$

\footnotetext{
$70 \quad$ APO, fasc. 6, 1265 .

71 Disney, A História de Portugal e do Império Português, vol. 2, 457-467; Antony, The GoaBahia Intra-Colonial Relations.

72 Ames, "Serving God, Mammon, or Both?: Religious Vis-à-Vis Economic Priorities in the Portuguese Estado Da India, c. 160o-170o".
} 
Regarding laws designed to encourage the conversion of orphans of Gentile parents, three controversial issues can be highlighted that were frequently discussed in the minutes of the Provincial Councils and in the legislation adopted by the Estado da India. The first was whether it was lawful to baptize orphaned children of Gentile parents before they reached the age of reason. The second was that, although the orphan judge was the official responsible for ensuring the removal of orphans (children of infidels) from their relatives' homes and handing them over to a Christian guardian, other agents ended up becoming involved in this task, such as the Pai dos Cristãos and the inquisitors of Goa, despite in principle it not being something under their jurisdiction. Maria Manso has demonstrated the involvement of the Pai dos Cristãos in situations of forced withdrawal of young people from such families, which encouraged complaints about this procedure. ${ }^{73}$ In 1646 , the Viceroy D. Filipe determined that the Pai dos Cristãos and other Jesuits, in places where there was an orphan judge, could only take the orphans if they had authorization from the viceroy or the orphan judge and were accompanied by a court official. ${ }^{74}$ However, the analysis below demonstrates that the Pai dos Cristãos was often accused of failing to comply with such determinations thereby exceeding the limits of his performance established by the laws, which displeased both the authorities of the Estado da Índia and the native population.

Regarding the involvement of the inquisitors in the issue of Gentile orphans, it is worth mentioning that the Goa Inquisition classified the habit of hiding orphans from Gentile families as a practice that was under the jurisdiction of the Holy Office and, for this reason, it persecuted "infidels" who hid orphans as they were seen as an obstacle to granting baptism to the orphans. ${ }^{75}$ In the 1640s, the archive of the Inquisition of Goa kept the records relating to the Pai dos Cristãos (Father Antônio Serqueira) and the orphans of the deceased Malagaro, who took up the right of customs collection on tobacco, as well as a certificate regarding the request of Recu Many, Gentile widow of Beru Chatim, against this measure - both examples of petitions presented by the disaffected Gentile population. ${ }^{76}$

The third issue to highlight in these controversies was the clash over the definition of who was to be considered an orphan. In general, as already discussed, the tendency was to consider anyone whose father had died as an

\footnotetext{
73 Manso, A Companhia de Jesus na Índia, 191.

74 APO, fasc. 6, $1265^{-1267 .}$

75 Lopes, "Goa: A simbiose luso-Oriental", 109.

76 Wicki, O Livro do Pai dos Cristãos, 304-305. Antr, Tribunal do Santo Ofício, Conselho Geral, mç. 36, no. 7; Faria, "A Inquisição de Goa e a Conversão Compulsória de Órfãos"; Chaturvedula, "Imperial Excess: Corruption and Decadence in Portuguese India", 271.
} 
orphan, even if his mother and grandparents were alive, which provoked several demonstrations of discontent among the non-Christian population. The decrees maintained the same nature of coercion of widows and relatives of Gentile orphans until 1677, coincidentally the same year in which an extremely violent episode occurred that led to the murder of a Pai dos Cristãos (a Franciscan) who, under orders from the Goa Inquisition, tried to remove orphans from their non-Christian families. ${ }^{77}$ The many complaints, petitions, and violent reactions prompted state officials in India to seek change in the practices and laws adopted.

Indeed, the Viceroy Antônio de Melo de Castro opposed the actions of the Goa inquisitors and interfered in the matter by asking them to release Mangoji Sinai, a tobacco contractor (rendeiro da Chancelaria e do tabaco de Bardez) condemned in the auto-da-fé celebrated in Goa on March 26, 1662, for having taken three orphans, his grandchildren, to the land of infidels and hiding them from the Portuguese authorities. The viceroy argued that the Inquisition disregarded royal provisions on orphans and interfered with the jurisdiction of the orphan judge. He explained that the kings of Portugal attributed the task, of taking the orphan boys and girls, to the orphan judge, while leaving it to the Pai dos Cristãos to learn about the Gentile parents who had died. The viceroy said that the Goa Inquisitor, Paulo Castelino, wanted this jurisdiction himself. However, an orphan was taken in Diu, a region where the Portuguese and ecclesiastical authority did not carry the same weight as they did in Goa, "as in that city there are greater privileges, and this introduction of the inquisitors was something new, it created such astonishment, that the next day three thousand or so residents moved to the land of the Moors".78

Glenn Ames has shown that complaints against the position adopted by the inquisitors were sent to the Kingdom of Portugal, due to the indirect financial losses suffered by the Estado da Índia, as the removal of orphans, would have been one of the stimuli for native merchants to leave for lands of neighboring kings (Muslims and Hindus) or for the English enclave of Bombay. ${ }^{79}$ The pressures exerted by the Gentiles could be carried out in several ways. Sometimes, they were individual petitions to receive exemption so that they did not need to comply with the standard, as was the case with Ramogy Sinay Cottary,

77 Faria, “A Inquisição de Goa e a conversão compulsória de órfãos”; Mendonça, Conversions and Citizenry: Goa under Portugal. 1510-1610.

78 Baião, A Inquisição de Goa: Tentativa de História de Sua Origem, Estabelecimento, Evolução e Extinção.

79 Ames, "Religious Life in the Colonial Trenches: The Role of the Pai dos Christãos in Seventeenth Century Portuguese India, c. 1640-1683". 
a Brahmin who served the Portuguese Crown as interpreter of the Estado da Índia and a resident of Bicholim, who stated that he wished to move to Goa. He was "wanting to bring his wife, children and more family to this city, and live in it". 80 Then, he requested permission to live in the lands of the Portuguese Crown and that after his death his descendants would not be taken as if they were orphans, nor would their property be confiscated. In addition, he requested that his children's mother be able to maintain their guardianship and that none of his relatives be harassed because of the orphans.

Jorge Flores explains that Cottary made the aforementioned claim after having watched the confiscation of the assets of the deceased Krishna Sinai, whose son-in-law, Vitoji Sinai, was Cottary's nephew. Additionally, Cottary would also have acted alongside the viceroy to prevent the Gentile Mangoji Sinai from having his sentence of exile to Mozambique executed. ${ }^{81}$ These two examples refer to the existence of important local groups of Hindus, whose objective was to "increase the share of the income held by a particular community", protecting the interest of its members. Michael N. Pearson studied the networks formed by such "holders of rendas, and their relatives and caste associates", identifying, among such tenants, the role of Mangoji Sinai in the midst of these networks of Hindu relatives and guarantors. ${ }^{82}$

In addition to petitions like those of Cottary, other forms of protest were collective. On March 30, 1677, the Prince Regent reported having learned of a petition by the "Gentile people" against the compulsory withdrawal of orphans from the guardianship of their Gentile relatives. ${ }^{83}$ In December of 1677 , the Viceroy D. Pedro de Almeida - under the order of the Prince Regent-summoned a board that met in Goa to evaluate the petition of the Gentile people, who wanted the application of legislation on orphans based on the aforementioned law of 1559 which considered children orphans only if they had no father, mother, or other living ascendants. Apart from the Goa Inquisitor Francisco Delgado e Matos, the opinions of those present at the board favored the application of the 1559 law.

Chancellor Manuel Martins Madeira pointed out that according to "civil and national law" (direito civil e pátrio) those with no father were considered orphans, even if they had a living mother and grandparent. However, his opinion was favorable to the 1559 law as it was created by the king to be applied to

80 Pissurlencar, Assentos do Conselho de Estado, fasc. 4, 33-34.

81 Flores, “Religião, 'Nação', Estatuto: Os Desafios de uma 'Dinastia' de Intérpretes Hindus na Goa Seiscentista”, 555 .

82 Pearson, "Coastal Western India: Studies from the Portuguese Records", 101.

83 ANTt, Tribunal do Santo Ofício, Conselho Geral, liv. 102, fol. 16v. 
the Christianity formed by his vassals who lived in the East. ${ }^{84}$ Thus, the chancellor defended the primacy of a particular law (that instituted by D. Sebastião for his vassals in the East) over the general (civil law, Ordinances of the Kingdom of Portugal) ${ }^{85}$

One argument used by the Chancellor and the Chief Revenue Superintendent, António Paes de Sande, was based on issues concerning "the political government, and the conservation of this state", so that both highlighted the negative impact of the withdrawal of orphans from Gentile families on the finances of the Estado da Índia. ${ }^{86}$ However, some arguments presented by civil and ecclesiastical authorities were stated in accordance with the assumptions of "Catholic politics" or "prudent theology" (Theologia prudente), as a Jesuit active in Goa called it. ${ }^{87}$ Prudent theology considered both "state reasons" (razões de Estado) and "supernatural reasons" (razões sobrenaturais) in order to achieve the supreme purpose, that is, to stimulate conversion. It was based on political foundations, as it aimed to avoid disturbances in the republic. Thus, political action conformed to justice, defined in a Christian way as the peace of the various interests unified in the common good. ${ }^{88}$ In the following statement by Chancellor Madeira, the maintenance of the Gentiles and their business in Portuguese territories was the sine qua non condition to create a viable rise in conversions: if the lands managed by the Crown are sustained with rent and goods, the conversion of Gentiles can be hoped, which would be impossible if they left for the lands of Muslim or Hindu kings.

The archbishop of Goa accommodated the temporal and spiritual reasons in a balanced way. He considered that, although civil law and the Ordinances of the Kingdom of Portugal defined orphans as only those who did not have a living father, princes could "lay down particular laws in derogation from general ones", defending the prevalence of the particular over the general, as the Chancellor had done. In addition, he evoked the principles of legal pluralism and localism, which adjusted to imperial contexts, in which sovereigns could adopt different laws, according to the diversity of territories and the nature of their vassals. ${ }^{89}$ Soon, the law of 1559 was adjusted to the diversity that existed in the Estado da Índia.

84 Pissurlencar, Assentos do Conselho de Estado, vol. 4, 280-287.

85 See: Hespanha, "Depois do Leviathan", 57; Hespanha, Cultura Jurídica Europeia - Síntese de um Milênio.

86 Pissurlencar, Assentos Do Conselho de Estado, vol. 4, 280-287.

87 APO, fasc. 6, supp., 25. Father Manuel de Sá, S.J. (1713). “[...] razão política canonizada por santa em toda a Theologia [...]".

88 Hansen, "Razão de Estado", 147.

89 "que os príncipes possão estatuir leis particular em derrogação das gerais, não padece dúvida [...] além de ser máxima dos Príncipes conquistadores, que dominam várias 
A second board met on January 12, 1678, which maintained the precedent opinion that Gentiles who had a mother, grandparents, or other living Gentile ascendants were not to be considered orphans. ${ }^{90}$ In the final years of the 17th century and in the first decades of the following one, the pressures of the native population encouraged the adoption of a more favorable definition of "orphan" for the Gentiles. In addition, the documentation demonstrates how the native population constantly denounced the way in which agents (judges, Pai dos Cristãos, inquisitors) acted, which was perceived locally as affronts to their customs or abuses by Crown officials who acted without the backing of royal laws. In the latter case, Gentiles were not refusing to obey the royal order, but rather what they considered to be the wrong forms of its application, associated with what they considered to be disrespect and affronts perpetrated by some officials. Concerning the abuses, at the beginning of the 18th century the Gentiles of Goa sent a complaint to the King of Portugal to denounce the Pai dos Cristãos, who was removing boys and girls from the bosom of Gentile families, even those who had a father and other living ascendants, that is, without observing the royal legislation itself. ${ }^{91}$

It is also interesting to note that Gentiles began to demand certain procedures from the officials of the Estado da Índia when they went to pick up the orphans-procedures that were not provided for in the minutes of the provincial councils or in the royal legislation: "When we took some orphans, the Gentiles used to require we ask them questions to know whether or not they want to be Christians". It was a procedure that the Gentiles wished to impose on the Portuguese authorities, even though the kings of Portugal never ordered them "to ask such orphans such questions".92 The actions of the Pai dos Cristãos sought to put into practice the decrees of the Provincial Councils of Goa, which established the obligation for the Gentile vassals of the Portuguese Crown to hear preaching regularly. Another determination that the Pai dos Cristãos sought to implement was the creation of Gentile rosters in order to learn, above all, of the existence of their orphaned children. However, the context in which the Pai dos Cristãos was denounced by the Gentiles, the early years of the 18th century, was different from that in which the Provincial Councils of Goa were celebrated, when several determinations were approved to force the Gentile vassals to have contact with Christian doctrine, like the one regarding preaching.

Províncias e estados, [podem] regê-los e governá-los com diferentes leis, conformandose com a diferença natural dos sogeitos, e vassalos que nelle vivem". Pissurlencar, Assentos do Conselho de Estado, vol. 4, 285. 
To demonstrate their discontent, there were many complaints which the Gentiles sent to the King of Portugal. A controversy that occurred in 1715 centers on one of the practices denounced by the Gentiles; Gentile vassals of the Portuguese Crown reacted to what they considered to be disrespect, abandoning the Portuguese conquests and going to neighboring lands, after the Pai dos Cristãos (Father Afonso da Costa) asked the Cathedral Chapter of Goa for authorization for a vicar to enter their homes in order to draw up a list of the names of the orphans. According to the customs of the Gentiles, when lists were made, they had to be made by mazanes (or cabeças) ${ }^{93}$ who were designated for "such lists, as they have often been used without repugnance", because the Gentiles felt affronted if "Christians or Ministers of the Church" entered "their homes, which has never been practiced, nor should it be practiced, because it is an affront". ${ }^{94}$

Indeed, the Jesuit Manuel de Sá was consulted on the matter and explained that the custom was that the mazanes were the agents responsible for the creation of the rolls with the names of the Gentiles: "When the viceroys ordered these people to be rostered, it was by calling the mazanes, or the heads, and they themselves went through the neighborhoods [...] putting all the Gentiles on the list: this was always the style observed, and it was always done". However, the procedure adopted by the Pai dos Cristãos, not following the traditional way of producing the rolls, caused great discontent: "now what was done [...] was entering $[. .$.$] the most secret chambers of these men's homes" where "their$ wives and daughters are, which is a most serious injury". 95

In addition, according to "the national customs of these Gentiles", it was enough that "someone from another caste see the pot where they cook for them to not use it anymore". ${ }^{96}$ The manner in which priests entered their houses to make the rolls caused many troubles for the Gentiles. Father Manuel de Sá considered that "it cannot be argued that this, and other customs that [the Gentiles] observe, are barbaric, because whether it is barbaric or not, it is their custom. And if they enter his interior houses, or force him to show his women, he has this for affront and injury, and is reviled among the most as a man without honor". ${ }^{77}$ In short, Manuel de Sá stated that the Gentiles did not

\footnotetext{
93 Mazanes (mahâ jan, that is, great men) are the notables of the Hindu community. Thomaz, "Amchi Bhas: O paradoxo linguístico de Goa", 179.

APO, fasc. 6, supp., doc. 12, 20. January 10, 1716. Emphasis added to highlight the idea of novelty and the introduction of changes that affronted the Gentiles and did not respect their customs.

95 APO, fasc. 6, supp., 45-46. Emphasis added.

96 APO, fasc. 6, supp., 45. Emphasis added.

97 APO, fasc. 6, supp., 45. Emphasis added.
} 
repudiate the law instituted by the King of Portugal, but to the way the Pai dos Cristãos tried to enforce it, neglecting the socially accepted customs and offending their honor.

The viceroy requested opinions from the State Council and religious officials on the subject. In addition, he stressed that the law itself that established the mandatory attending of preaching and the inclusion of the names of Gentiles on lists did not apply to all Gentiles. ${ }^{98}$ One of the appraisers, Manuel de Sá, also recalled the privileges granted to some of the Gentile vassals of the Crown, such as tenants, high-skilled artisans, and shopkeepers, who were exempt from the aforementioned obligations. ${ }^{99}$

Regarding the incident of 1715 , the King of Portugal, through the advisers of the Overseas Council, expressed his support for the decision made by the Viceroy to suspend the procedures that were being adopted by the Pai dos Cristãos, in relation to the obligation of the Gentiles to listen to preaching and the creation of the Gentile rosters without respecting local customs. ${ }^{100}$ In general, the Viceroy had determined that the Gentiles could return to the Portuguese conquests in a safe manner, without having to attend preaching and that the rolls would be executed at the time he deemed convenient. ${ }^{101}$

The controversies surrounding the laws aimed at the conversion of orphaned children of Gentile parents and their relatives allow for the unravelling of the complex plot concerning the construction of rules and their application in the Estado da Índia. If in the normative scope the problem had institutions, agents, and their jurisdictions supposedly well defined, as the decree of the Fifth Provincial Council of Goa emphatically defended, ${ }^{102}$ the interpretation of the norm concerning orphans and its application, in turn, have been the subject of intense disputes over the decades and centuries, involving judges of orphans, the Pai dos Cristãos, inquisitors, viceroys, vicars, and, of course, family members of the orphans. It can be said that the pressures exerted by the Gentile families (writing of petitions to the King of Portugal, abandonment of Portuguese lands, acts of murder against the agents who took the orphans) led local authorities of the Estado da Índia to seek ways to compromise on the rules through recognizing the legitimacy of part of the demands of the Gentiles, including respect for their customs, such as being included in rosters made only by the mazanes, which was agreed on at the beginning of the 18 th century.

\footnotetext{
98 APO, fasc. 6, supp., 26. Manuel de Sá was a Jesuit and Patriarch of Ethiopia.

99 APO, fasc. 6, supp., 25-27. Goa, July 3, 1715.

100 APO, fasc. 6, supp., 71-73. Lisbon, January 14, 1717.

101 APO, fasc. 6, supp., 22. Goa, January 10, 1716.

102 APO, fasc. 4, 207 (5th Council, action 2, dec. 7).
} 
This chapter has analyzed the responses that ecclesiastics and other authorities present in the provincial councils sought to give to local challenges in search of the establishment of norms that would regulate the relations between Christians and non-Christians in the Archbishopric of Goa, in parallel with the efforts to promote the conversion of local populations that were quite diverse. The conciliar decrees, therefore, intended to build norms to try to control this multiplicity of presences, belongings, and statutes.

The minutes from these councils also express very clearly that without the support of different justices, agents, and powers it would be impossible to implement the idealized norms to order the relations between Christians and non-Christians in the Archbishopric of Goa. In this sense, the minutes of the Provincial Councils of Goa are replete with requests to the King of Portugal or to the viceroy (or governor) for specific regulations to be drawn up or for efforts to be made to comply with existing laws regarding matters in which the secular and spiritual domains were highly interwoven. The normative production over non-Christian populations was therefore the result of the interaction between different agents and institutions.

Although the political and economic contexts related to the Kingdom of Portugal and the Estado da Índia underwent changes between the celebration of the First (1567) and the Fifth Provincial Council of Goa (1606), the conciliar decrees maintained the same tone, sustaining the ambition to promote the systematic conversion of local populations, at least in the central and more controlled spaces of the Estado da Índia. At the discursive level, the supposed confluence of political and religious interests is combined in the minutes of the five provincial councils - although the positions of civil and ecclesiastical agents revealed different inclinations in other contexts of normative production, embracing a more austere or moderate policy of proselytism. ${ }^{103}$

In the context of the late 17 th century and the early decades of the 18th century, when the Estado da Índia itself had already changed its configuration, civil and ecclesiastical authorities emphasized that it was imperative to review actions in search of conversions, being difficult to maintain the evangelical fervor typical of the period in which the first provincial councils took place. The issue of conversions was accompanied by considerations about the nature of political actions that guaranteed the conservation of the Estado da Índia. In a memorial written at the end of the 17th century, Manuel Gonçalves Guiãojudge of the Court of Appeal of Goa who was appointed Conservador e Juiz dos

103 Mendonça, Conversions and Citizenry: Goa under Portugal. 1510-1610; Xavier, A Invenção de Goa: Poder Imperial e Conversões Culturais nos Séculos XVI e XVII. 
Cristãos da Terra ${ }^{104}$ — was in favor of prudence and diplomacy, recommending good correspondence with the Gentile and Moorish kings who authorized the presence of Christians in their lands, but who were scandalized when their vassals were oppressed. Despite having held a position at the local institution more radically associated with religious Christianization projects- the Inquisition of Goa-Guião argued that the ministers of the Holy Office needed to be endowed, above all, with "prudence, speech, and politics" (prudência, discurso, e politica) to achieve the preservation of Christianity in the East, arguing that the loss of a rebellious soul is less important than the loss of all Christianity. ${ }^{105}$

Another conclusion is that the assignments of the Pai dos Cristãos were subject to dynamic normative construction throughout the period under investigation, that is, from the 1530s, when the position was created, to the 1720 s, when the Rules of Procedure were drawn up for the Conservador e Juiz dos Cristãos da Terra. The offices of Pai dos Cristãos and Conservador e Juiz were instituted locally and dealt with very specific issues related to conversion, including judicial action in cases involving native Christians and the treatment of issues related to orphaned children of Gentile parents.

After the order of D. João v, the Rules of Procedure for the Newly Converted and Gentile Orphans was created (1724), on the basis of which the Paidos Cristãos should only notify the Conservador e Juiz of the existence of orphaned children of Gentiles, without being able to remove them from their homes. According to the Rules, the Conservador e Juiz would have the same powers as the orphan judge (for example, preparing inventories) and would act as a private judge in civil cases or crimes involving converted natives or Gentile orphans, while the Pai dos Cristãos would have his functions reduced to spiritual matters. ${ }^{106}$

In practice, the aforementioned Rules of Procedure and other forms of regulation do not seem to have prevented some Pais dos Cristãos from continuing to act in spheres that, according to the regulations, never or no longer belonged to them, causing constant dissatisfaction from authorities and native populations. This was responsible for several denunciations of possible abuses, in the case of the practice of preparing rosters with the names of Gentiles, entering their homes, and cutting off the sendy (tail they wore on their heads) so that they would lose their caste and be baptized, that is, an action in search of conversions that had been prohibited since the First Provincial Council of Goa. ${ }^{107}$

\footnotetext{
104 On Manuel Guião, see: Lourenço, "Uma Inquisição Diferente. Para uma leitura institucional do Santo Ofício de Goa e do seu distrito (séculos XVI e XVII)".

105 ANTT, Conselho Geral do Santo Ofício, mç. 36, no. 29, fol. 1r. Guião was appointed promotor and, later, inquisitor of the Holy Office of Goa.

106 APO, fasc. 4, supp., 113-118; "Regimento dos novamente convertidos, e órfãos gentios".

107 APO, fasc. 6, 305.
} 
The threats exerted by the Gentiles did not lead to the total repeal of the law that authorized the removal of orphans from the home of their Gentile relatives. This means that the withdrawal of such orphans did not come to be understood by agents of the Portuguese Crown and the Church as an undoubtedly violent action - used to stimulate baptisms - which needed to be prohibited to be in line with provincial councils that prevented the use of force to favor conversions. However, it is important to recognize the role of the native population itself in the construction of norms, more precisely, in the issues that involved the removal of orphans from their kin groups. In this chapter, some Gentiles emerge in petitions involving the controversial orphan conversion policy: Mangoji Sinai, who took up the right of customs collection on tobacco; Malagaro, tax-collector of the Bardez Customs; Many, widow of Beru Chatim; ${ }^{108}$ and Cottary, an interpreter and diplomatic agent of the Estado da Índia. They were merchants, tax collectors, financiers, that is, people who had an important economic or diplomatic role for the Estado da Índia, whose actions demonstrate the capacity of such local groups to explore existing legal spaces and that their demands were considered in the interpretation and decision of cases.

When the minutes of the Provincial Councils of Goa are compared with other documentary sources, one sees how the social pressures exerted locally impacted the reformulation (or rejection) of some norms that tried to order the relationship between Christians and non-Christians. Thus, in the last quarter of the 17th century, the interpretation that brought more contentment to the local non-Christian population was that the Gentile orphan would be liable to be handed over to a Christian guardian if he or she had no living paternal or maternal ascendants, that is, this interpretation prevailed over some of the decrees of the Provincial Councils of Goa which advocated handing over the orphans to a guardian after the death of the Gentile father, even though the boys and girls had other living ascendants. From a diachronic perspective, it can be considered that local pressures played an important role in the way in which the norms concerning orphans were interpreted in Goa. In short, local interests and challenges faced by Portuguese institutions and agents established in Asia, as well as complaints and other forms of contestation of such rules by native populations, led to changes in the interpretation of such laws, resulting in the definition of norms that suggested forms of compromise or efforts toward accommodation of Gentile customs.

108 Chatim was a term used to designate merchants or more specifically a type of rich gemstone merchant. 


\section{Acknowledgements}

I would like to thank Manuel Bastias Saavedra and the two anonymous reviewers for their suggestions. I also thank Genevieve Beech for her work on the English version of this text.

\section{Bibliography}

\section{Manuscripts}

Arquivo Nacional da Torre do Tombo, Lisbon (ANTT), Tribunal do Santo Ofício, Conselho Geral, mç. 36, no. 7 .

Arquivo Nacional da Torre do Tombo, Lisbon (ANTT), Tribunal do Santo Ofício, Conselho Geral, liv. 102.

Arquivo Nacional da Torre do Tombo, Lisbon (ANTT), Conselho Geral do Santo Ofício, mç. 36 , no. 29 .

Biblioteca Nacional de Portugal, Lisbon (BNP), Cod. 176.

\section{Printed Sources}

Aquino, Tomás de, Suma Teológica, ed. Pereira, Joaquim, São Paulo 2001.

Pissurlencar, Panduronga, Assentos do Conselho de Estado, Bastorá 1953.

Rego, António da Silva, Documentação para a História das Missões do Padroado Português do Oriente, vol. 10, Lisboa 1995.

Rivara, Joaquim Heliodoro Da Cunha, Archivo Portuguez-Oriental, Delhi 1992.

Sacrosanto, e Ecumênico Concílio de Trento, em Latim e Portuguez, Lisboa 1781: Na Officina Patriarc. de Francisco Luiz Ameno.

Wicki, Joseph, O Livro do Pai dos Cristãos, Lisboa 1969.

\section{Literature}

Ames, Glenn, "Serving God, Mammon, or Both?: Religious Vis-à-Vis Economic Priorities in the Portuguese Estado da India, c. 1600-1700", in The Catholic Historical Review 86, no. 2 (2001): 193-216.

Ames, Glenn, "Religious Life in the Colonial Trenches, The Role of the Pai dos Christãos in Seventeenth Century Portuguese India, c. 1640-1683", in Portuguese Studies Review 16, no. 2 (2008): 1-23.

Antony, Philomena, The Goa-Bahia Intra-Colonial Relations, Tellichery 2004.

Araújo, Maria Benedita, “O 'Pay dos Christãos'. Contribuição para o Estudo da Evangelização da Índia”, in Missionação Portuguesa e Encontro de Culturas. Actas do Congresso Internacional de História, Braga 1993, 305-324. 
Baião, António, A Inquisição de Goa: Tentativa de História de Sua Origem, Estabelecimento, Evolução e Extinção, Lisboa 1945.

Bethencourt, Francisco, "A Igreja", in Bethencourt, Francisco and Kirti Chaudhuri (eds.), História da Expansão Portuguesa, Navarra 1998, 369-386.

Boschi, Caio, "Estruturas Eclesiásticas e Inquisição", in Bethencourt, Francisco and Kirti Chaudhuri (eds.), História da Expansão Portuguesa, Navarra 1998, 426-459.

Boschi, Caio, "Os Escritos de D. Frq1ei Manuel da Cruz e as Constituições Primeiras do Arcebispado da Bahia", in Feitler, Bruno and Evergton Sales Souza (eds.), A Igreja no Brasil: Normas e Práticas durante a Vigência das Constituições Primeiras do Arcebispado da Bahia, São Paulo 2011, 399-424.

Cardim, Pedro, "Os Povos Indígenas, a Dominação Colonial e as Instâncias da Justiça na América Portuguesa e Espanhola”, in Domingues, Ângela, Maria Leônia Chaves de Resende and Pedro Cardim (eds.), Os Indígenas e as Justiças no Mundo Ibero-Americano (Sécs. XVI-XIX), Lisboa 2019, 29-84.

Chaturvedula, Nandini, Imperial Excess: Corruption and Decadence in Portuguese India (PhD Thesis), Columbia 2010.

Coates, Timothy, Degreados e Órfãs: Colonização dirigida pela Coroa no Império Português. 1550-1755, Lisboa 1998.

Coutinho, Fortunato, Le Régime Paroissial des Diocèses de Rite Latin de l'Inde des origines (XVIe Siècle) à nos jours, Louvain 1958.

Disney, Anthony, A História de Portugal e do Império Português, Lisboa 2011.

Duve, Thomas, "Pragmatic Normative Literature and the Production of Normative Knowledge in the Early Modern Iberian Empires in the 16th-17th Centuries", in Duve, Thomas and Otto Danwerth (eds.), Knowledge of the Pragmatici: Legal and Moral Theological Literature and the Formation of Early Modern Ibero-America, Leiden 2020, 1-39.

Faria, Patricia Souza de, "Os Concílios Provinciais de Goa: Reflexões sobre o impacto da 'Reforma Tridentina' no centro do Império Asiático Português (1567-16o6)”, in Topoi 14, no. 27 (2013): 218-238.

Faria, Patricia Souza de, "A Inquisição de Goa e a Conversão Compulsória de Órfãos", in Silva, Marco Antônio Nunes da Silva and Suzana Maria de Sousa Santos Severs (eds.), Estudos Inquisitoriais: História e Historiografia, Cruz das Almas (Brazil) 2019.

Ferreira, André Luís Bezerra, Nas Malhas da Liberdade: O Tribunal da Junta das Missões e o Governo dos Índios na Capitania do Maranhão - 1720-1757 (MA Thesis), Belém 2017.

Flores, Jorge, “Religião, 'Nação', Estatuto: Os desafios de uma 'Dinastia' de intérpretes hindus na Goa Seiscentista", in Monteiro, Rodrigo Bentes, Bruno Feitler, Daniela Calainho, and Jorge Flores (eds.), Raízes do Privilégio: Mobilidade Social no Mundo Ibérico do Antigo Regime, Rio de Janeiro 2011, 537-565.

Gandelman, Luciana Mendes, Entre a Cura das Almas e o Remédio das Vidas: O Recolhimento de Órfãs da Santa Casa da Misericórdia do Rio de Janeiro - ca. 1739-1830 (MA Thesis), Campinas 2001. 
Gonçalves, Nuno da Silva, "Padroado", in Azevedo, Carlos Moreira, Dicionário de História Religiosa de Portugal, Lisboa 2001, 364-368.

Hansen, João Adolfo, "Razão de Estado", in Novaes, Adauto (ed.), A Crise da Razão, São Paulo 1999, 135-156.

Hernández, Ramón, Derechos Humanos en Francisco de Vitoria: Antología, San Esteban 1984.

Hespanha, António Manuel, "Depois do Leviathan”, in Almanack Braziliense o, no. 5 (2007): 55 .

Hespanha, António Manuel, Cultura Jurídica Europeia - Síntese de um Milênio, Coimbra 2012.

Hespanha, António Manuel, "Uncommon Laws. Law in the Extreme Peripheries of an Early Modern Empire", Zeitschrift Der Savigny-Stiftung Fur Rechtsgeschichte, Germanistische Abteilung 130, no. 1 (2013): 180-204.

Lopes, Maria de Jesus dos Mártires, “Goa: A Simbiose Luso-Oriental”, in Serrão, Joel and António Henrique de Oliveira Marques (eds.), Nova História Da Expansão Portuguesa: O Império Oriental: 1660-1820, Lisboa 2006.

Lourenço, Miguel Rodrigues, "Uma Inquisição Diferente. Para uma Leitura Institucional do Santo Ofício de Goa e do Seu Distrito (Séculos XVI e XVII)", in Lusitania Sacra 31 (2015): 129-164.

Madeira-Santos, Catarina, Goa é a Chave de Toda a Índia. Perfil Político da Capital do Estado da Índia (1505-1570), Lisboa 1999.

Madeira-Santos, Catarina, "O Império Português Face às Instituições Indígenas (Estado Da Índia, Brasil e Angola, Séculos XVII-XVIII)”, in Xavier, Ângela Barreto, Federico Palomo and Roberta Stumpf, Monarquias Ibéricas em Perspectiva Comparada (Sécs. XVI-XVIII), Lisboa 2018, 271-302.

Manso, Maria de Deus Beites, A Companhia de Jesus na Índia (1542-1622). Actividades Religiosas, Poderes e Contactos Culturais, Macau 2009.

Martínez López-Cano, María del Pilar (ed.), Concilios Provinciales Mexicanos. Época Colonial, Ciudad de México 2014.

Mello, Márcial Eliane Alves de Souza e, "Sobre as Apelações de Liberdade dos Índios na Amazônia Portuguesa No Século XVIII", in II Jornada Nacional de História do Trabalho, Florianópolis 2004.

Mendonça, Délio de, Conversions and Citizenry: Goa under Portugal.1510-1610, Delhi 2002.

Moutin, Osvaldo R., "Producing Pragmatic Literature in the Third Mexican Provincial Council (1585)", in Duve, Thomas and Otto Danwerth (eds.), Knowledge of the Pragmatici: Legal and Moral Theological Literature and the Formation of Early Modern Ibero-America, Leiden 2020, 282-295

Newitt, Malyn, "Formal and Informal Empire in the History of Portuguese Expansion", in Portugueses Studies 17 (2001): 1-21.

Paiva, José Pedro, "A Recepção e Aplicação do Concílio de Trento em Portugal”, in Paiva, José Pedro, Savid Sampaio Barbosa and António Camões Gouveia (eds.), O Concílio de Trento Em Portugal e Nas Suas Conquistas: Olhares Novos, Lisboa 2014, 13-40. 
Pearson, Michael N., Coastal Western India: Studies from the Portuguese Records, Delhi 1981.

Pissurlencar, Panduronga, Assentos do Conselho de Estado, Bastorá 1953.

Porras Camúñez, José Luis, Sínodo de Manila de 1582, Madrid 1988.

Robinson, Rowena, Conversion, Continuity and Change, Delhi 1998.

Sá, Isabel dos Guimarães, "Estruturas Eclesiásticas e Acção Religiosa", In Bethencourt, Francisco and Diogo Ramada Curto (eds.), A Expansão Marítima Portuguesa, 1400180o, Lisboa 2007, 265-292.

Silva, Amélia Maria Polónia da, "Recepção do Concílio de Trento em Portugal: As Normas Enviadas pelo Cardeal D. Henrique aos Bispos do Reino, em 1553", in Revista da Faculdade de Letras - História 7 (1990): 133-144.

Subrahmanyam, Sanjay, O Império Asiático Português. 1500-170o, Lisboa 1995.

Tavares, Célia Cristina da Silva, Jesuítas e Inquisidores em Goa, Lisboa 2004.

Thomaz, Luiz Filipe, De Ceuta a Timor, Lisboa 2004.

Thomaz, Luís Filipe, "Amchi Bhas: O Paradoxo Linguístico de Goa", in Povos e Culturas $20(2017): 145^{-214}$.

Vila-Santa, Nuno, "O Vice-Reinado de D. Antão de Noronha no Contexto da Crise do Estado da Índia de 1565-1575”, in Anais de Historia de Além-Mar, no. 10 (2010): 7-48.

Vila-Santa, Nuno. "Revisitando o Estado da Índia nos anos de 1571 a 1577", in Revista de Cultura 36 (2010): 88-112.

Vila-Santa, Nuno, "Resistência e Contemporização: Tensões Políticas na Implementação da Contra-Reforma no Estado da Índia (1557-1580)", in Avelar, Ana Paulo, Margarida Lalanda, and Paulo Lopes (eds.), Martinho Lutero e Portugal: Diálogos, Tensões e Impactos, Lisboa 2019, 153-172.

Wicki, Joseph, "Die Konzilien Der Kirchenprovinz Goa : 1567-1895”, in Annuarium Historiae Conciliorum 12 (1983): 155-270.

Wicki, Joseph, O Livro do Pai dos Cristãos, Lisboa 1969.

Xavier, Ângela Barreto, "Gaspar de Leão e a Recepção do Concílio de Trento no Estado da Índia”, in Paiva, José Pedro, David Sampaio Barbosa, and António Camões Gouveia (eds.), O Concílio de Trento em Portugal e nas Suas Conquistas: Olhares Novos, Lisboa 2014, 133-159.

Xavier, Ângela Barreto, A Invenção de Goa: Poder Imperial e Conversões Culturais nos Séculos XVI e XVII, Lisboa 2008.

Xavier, Ângela Barreto and Fernanda Olival, "O Padroado Da Coroa de Portugal: Fundamentos e Práticas”, in Xavier, Ângela Barreto, Federico Palomo and Roberta Stumpf, Monarquias Ibéricas em Perspectiva Comparada (Sécs. XVI-XVIII), Lisboa 2018, 123-16o. 